\title{
Podniesienie dna zatoki szczękowej metodą piezohydrodynamiczną z modyfikacją własną - opis przypadków
}

\author{
Maxillary sinus lift by the piezohydrodynamic method with author's modification \\ - a case study \\ ${ }^{1}$ Prywatna Klinika Implantologiczno-Stomatologiczna ZIĘTEK Clinic \\ ${ }^{2}$ Klinika Gerostomatologii, Uniwersytet Medyczny im. Karola Marcinkowskiego w Poznaniu
}

DOI: http://dx.doi.org/10.20883/df.2017.13

\begin{abstract}
Streszczenie
Zabieg podniesienia dna zatoki szczękowej jest obecnie jednym z coraz częściej wykonywanych zabiegów augmentacyjnych. Jest kilka metod wykonania tej procedury. Różnią się one traumatycznością, trudnością operacyjną i odsetkiem przerwania membrany Schneidera. Najczęściej zabieg ten jest wykonywany z klasycznego dojścia bocznego Caldwell-Luca, co czyni go relatywnie traumatycznym dla pacjenta. Dlatego też nie ustają wysiłki, aby opracować metody mniej traumatyczne, a przez to również bardziej przewidywalne (niosące ze sobą mniejszą ilość powikłań). Metodami takimi są piezohydrodynamiczne sposoby elewacji membrany Schneidera. W największej bibliotece PubMed jest mniej niż dziesięć artykułów traktujących o tym temacie. W artykule tym przedstawione zostały zabiegi sinus liftu wykonane przy pomocy urządzenia W\&H metodą piezohydrodynamiczną (Ziętek Piezo Crestal Lift Concept ${ }^{\circledR}$ ).
\end{abstract}

Słowa kluczowe: membrana Schneidera, podniesienie dna zatoki, niska traumatyczność, mała inwazyjność, piezochirurgia.

\begin{abstract}
A sinus lift is currently one of the most commonly performed augmentation procedures. There are a few methods for this bone augmentation. They differ between the minimum trauma, the surgical difficulty and the percentage perforation of the Schneider membrane. Lateral antrostomy using the Caldwell Luc surgical procedure is the most common but still the most traumatic one for the patient. Hence, a great deal of effort is being put in in order to find less traumatic but at the same time more predictable (reducing potential complications) techniques. These surgical procedures include hydrodynamic piezoelectric methods for extending the Schneider membrane. Unfortunately, the literature on this specific topic is extremely limited. In the largest library, PubMed, there are less than 10 articles on these innovative techniques. In the following article, sinus lift surgical procedures were performed with a W\&H surgical device utilizing a hydrodynamic piezoelectric technique in all cases (Ziętek Piezo Crestal Lift Concept $\left.{ }^{\circledR}\right)$.
\end{abstract}

Keywords: Schneiderian membrane, sinus lift, minimum trauma, minimaly invasive, piezosurgery.

Na powodzenie zabiegu implantologicznego składa się szereg czynników. Jednym z nich jest objętość kości. Jej ilość maleje stale, nawet przy zachowaniu własnego uzębienienia. Do gwałtownego zaniku dochodzi po utracie uzębienia. W odcinku bocznym szczęk do spadku ilości (wysokości) kości przyczynia się jeszcze zjawisko pneumatyzacji zatok szczękowych, polegające na powiększaniu się ich objętości w trakcie życia pacjenta w wyniku osteoklastycznego działania membrany Schneidera. Skutkiem tego bardzo często konieczne jest wykonanie zabiegu podniesienia dna zatoki szczękowej, czyli tzw. zabiegu sinus liftu, przed wykonaniem implantacji śródkostnych wszczepów.

Zabieg podniesienia dna zatoki szczękowej jest jednym z najczęściej wykonywanych zabiegów augmentacyjnych tkanek twardych. Wykonywany może być z dojścia bocznego przez wyrostek lub najczęściej z klasycznego dojścia Caldwella-Luca.

Zabieg sinus liftu wykonany $z$ dojścia przez wyrostek zębodołowy można wykonywać różnymi metodami: osteotomami (metoda Summersa), metodą balonikową (Soltan i Smiler), systemem wierteł do perforacji warstwy kortykalnej i wężyka ze strzykawką wypełnioną solą fizjologiczną, za pomocą której poprzez wzrost ciśnienia pomiędzy membraną Schneidera a ścianą zatoki szczękowej powoduje się odpreparowanie membrany (CAS kit), czy też przy użyciu urządzeń piezoelektrycznych piezochirurgicznych (W\&H, Acteon - Satelec).

Podniesienie dna zatoki szczękowej z dojścia bocznego ma wielu zwolenników, którzy argumen- 
tują za wyborem tej metody. Dobry wgląd w pole operacyjne, a przez to większe bezpieczeństwo wykonania zabiegu ma jednak swoje zalety. Niestety nie w każdym przypadku laceracja membrany jest widoczna, przez co czasami może dojść do powikłania zabiegu w postaci przedostania się granulek materiału augmentacyjnego do światła zatoki. Nie jest to z resztą jedyny minus tej metody. Innym może być dość znaczna traumatyczność, możliwość krwotoku czy ryzyko związane z uszkodzeniem membrany Schneidera w przypadku obecności przegrody wewnątrz zatoki. Nie bez znaczenia jest też wysoki koszt wykonania procedury.

Procedurą chirurgiczną, która jest pozbawiona powyższych wad, jest hydrodynamiczna metoda przy użyciu urządzeń piezoelektrycznych (piezohydrodynamiczna), która może być wykonywana na dwa sposoby.

Pierwszym sposobem jest IntraLift ${ }^{\circledR}$ (Acteon Satelec) drugim zaś własna metoda (Ziętek Piezo Crestal Lift Concept ${ }^{\circledR}$ ) opracowana wspólnie z firmą W\&H. Metoda autorska dostępna jest na rynku od II kwartału 2017 (Rycina 1).

IntraLift był pierwszą procedurą piezohydrodynamiczną na świecie. Metoda ta, zaproponowana przez Troedhana, Kurreka Wainwrighta, polega na użyciu pięciu specjalnych końcówek, z których cztery służą do „przejścia” przez wyrostek, perforacji warstwy kortykalnej ściany zatoki oraz powiększenia otworu. Niestety na tym etapie zabiegu dochodzi do kontaktu końcówki roboczej z membraną Schneidera, co może skutkować jej uszkodzeniem. Piąta końcówka, tzw. „trąbka”, służy do odpreparowania membrany od ściany zatoki. Uzyskuje się to poprzez wzrost ciśnienia soli fizjologicznej pomiędzy nimi oraz wykorzystanie mikrowibracji płynu dzięki występującemu zjawisku kawitacji.

W koncepcji prezentowanej w tej pracy wykorzystywana jest jedna końcówka, a jedynie w przypadku grubości wyrostka powyżej $4 \mathrm{~mm}$ używana jest końcówka do szybszego preparowania otworu (Rycina 2), do tego celu może również być użyte wiertło z kasety implantologicznej. Nawiert jest kończony około $1 \mathrm{~mm}$ od ściany zatoki. Jej perforacja wykonywana jest za pomocą głównej końcówki (Rycina 3), która wykorzystuje te same zjawiska zachodzące w roztworze soli fizjologicznej, co tak zwana „trąbka” w metodzie IntraLift.

Różnica pomiędzy dwoma wymienionymi sposobami jest taka, że w przypadku W\&H membrana zatoki nie jest dotykana w żadnym momencie perforacji ściany zatoki ani w trakcie jej odpreparowywania. Wynika to ze specjalnie zaprojektowanego kształtu końcówki (Rycina 4), dzięki któremu perforujemy ścianę zatoki, a chłodzeniem wewnętrznym podnosimy membranę Schneidera.

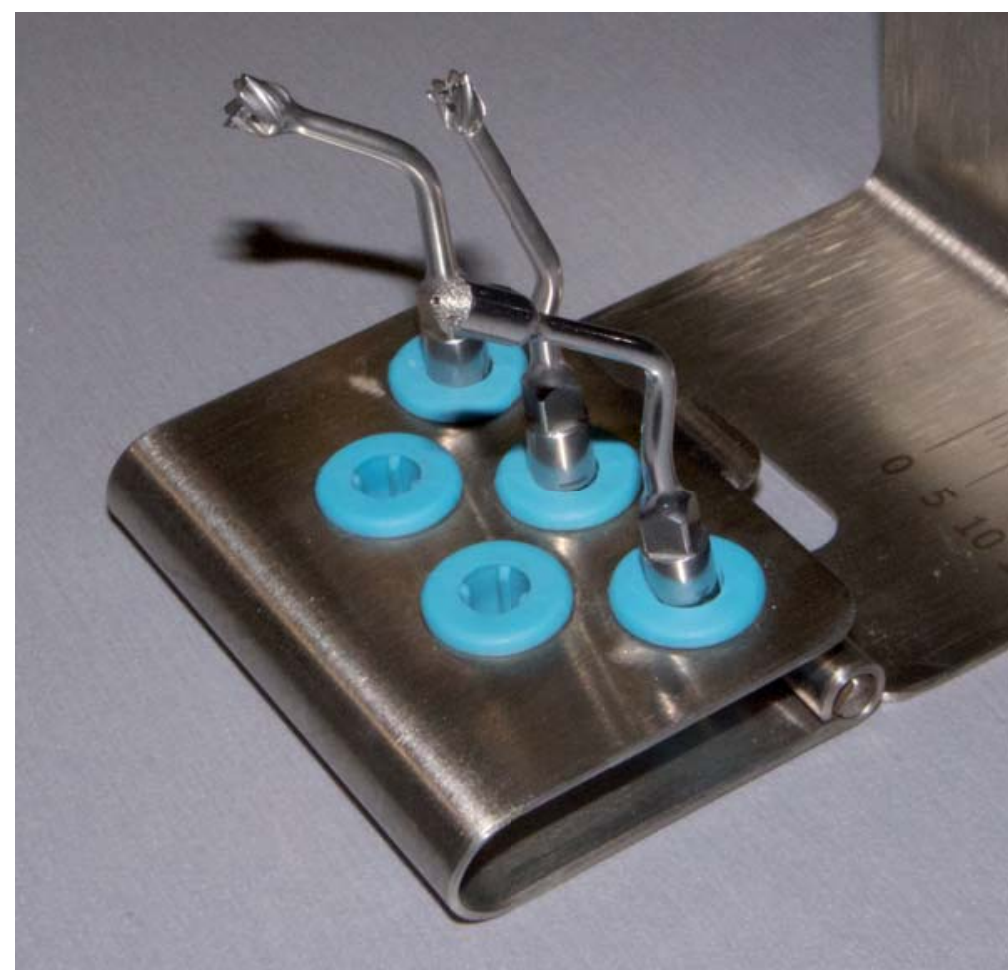

Rycina 1. Zestaw końcówek (głównej i pomocniczych) stosowanych do podniesienia zatoki szczękowej

Figure 1. Set of attachments (primary and secondary) used in maxillary sinus lift 


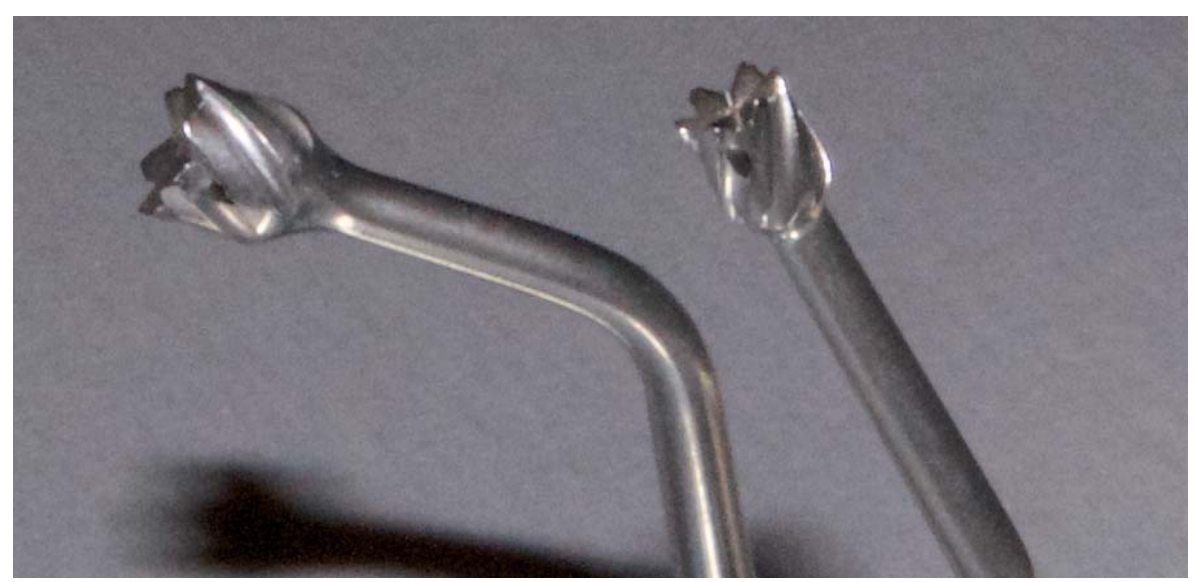

Rycina 2. Końcówki pomocnicze stosowane przy większej ilości kości przy dnie zatoki

Figure 2. Secondary attachment used for greater amount of bone at sinus bottom

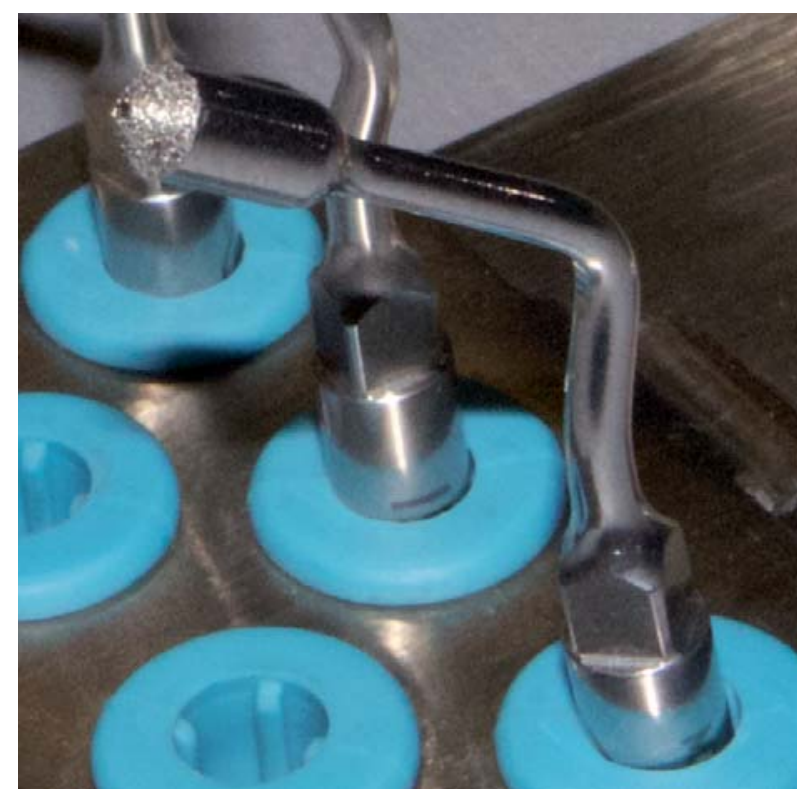

Rycina 3. Końcówka główna służąca do perforacji warstwy kortykalnej zatoki

Figure 3. Primary attachment for perforation of cortical sinus layer

Kolejną zaletą tej metody, oprócz niskiej traumatyczności i małej inwazyjności, jest lepsze zaopatrzenie materiału augmentacyjnego w krew, ponieważ naczynia krwionośne mogą wnikać do przeszczepu z każdej strony. Dlatego też uzyskuje się szybsze gojenie i mniejsze jest ryzyko przekroczenia krytycznej wielkości przeszczepu. Dzięki temu podczas jednego zabiegu możliwe jest podniesienie dna zatoki szczękowej o $10-15 \mathrm{~mm}$.

\section{Przypadek pierwszy}

Pacjentka zgłosiła się celem uzupełnienia braku drugiego zęba przedtrzonowego lewego, usuniętego kilka lat wcześniej.

Kontrolne zdjęcie rentgenowskie uwidoczniło niewystarczającą ilość kości wyrostka zębodoło-

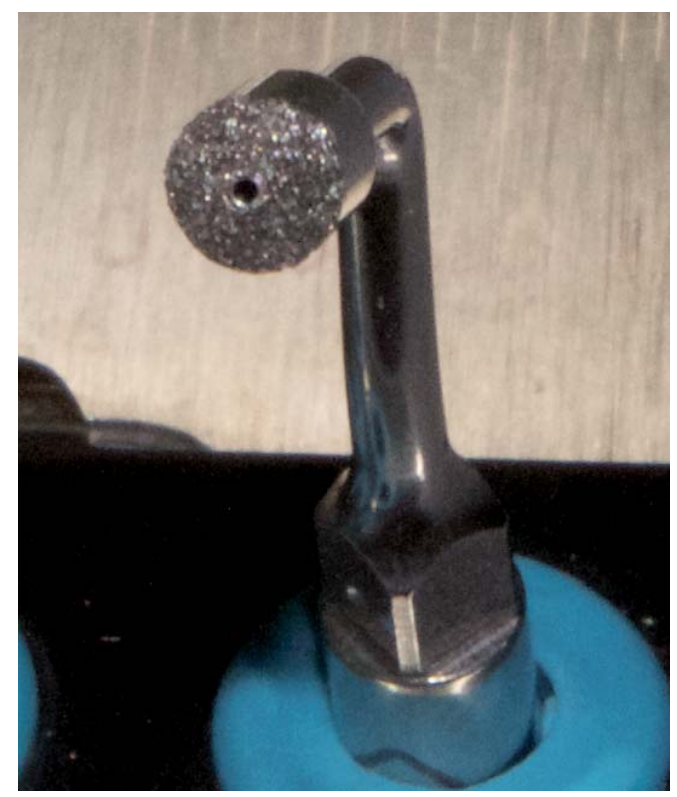

Rycina 4. Końcówka główna z chłodzeniem wewnętrznym

Figure 4. Primary attachment with internal cooling

wego pod dnem zatoki szczękowej, niezbędnego dla wszczepienia implantu. Zlecone badanie CBCT potwierdziło wcześniejszy wynik badania RTG. Na tej podstawie wysokość wyrostka wynoszącą 5,5 mm (Rycina 5) pozwoliła na wykonanie podczas jednego zabiegu podniesienia dna zatoki szczękowej i wszczepienie implantu.

Podniesienie dna zatoki zostało wykonane przy użyciu urządzenia piezoelektrycznego firmy W\&H. Wyrostek zębodołowy odsłonięto przez minimalne odpreparowanie płata śluzówkowego na szczycie wyrostka, bez pionowych cięć zwalniających. Nawiert został wykonany za pomocą wiertła $z$ kasety implantologicznej (Rycina 6), a warstwa kości kortykalnej dna zatoki sperforowana za pomocą końcówki urządzenia piezoelektrycznego. 

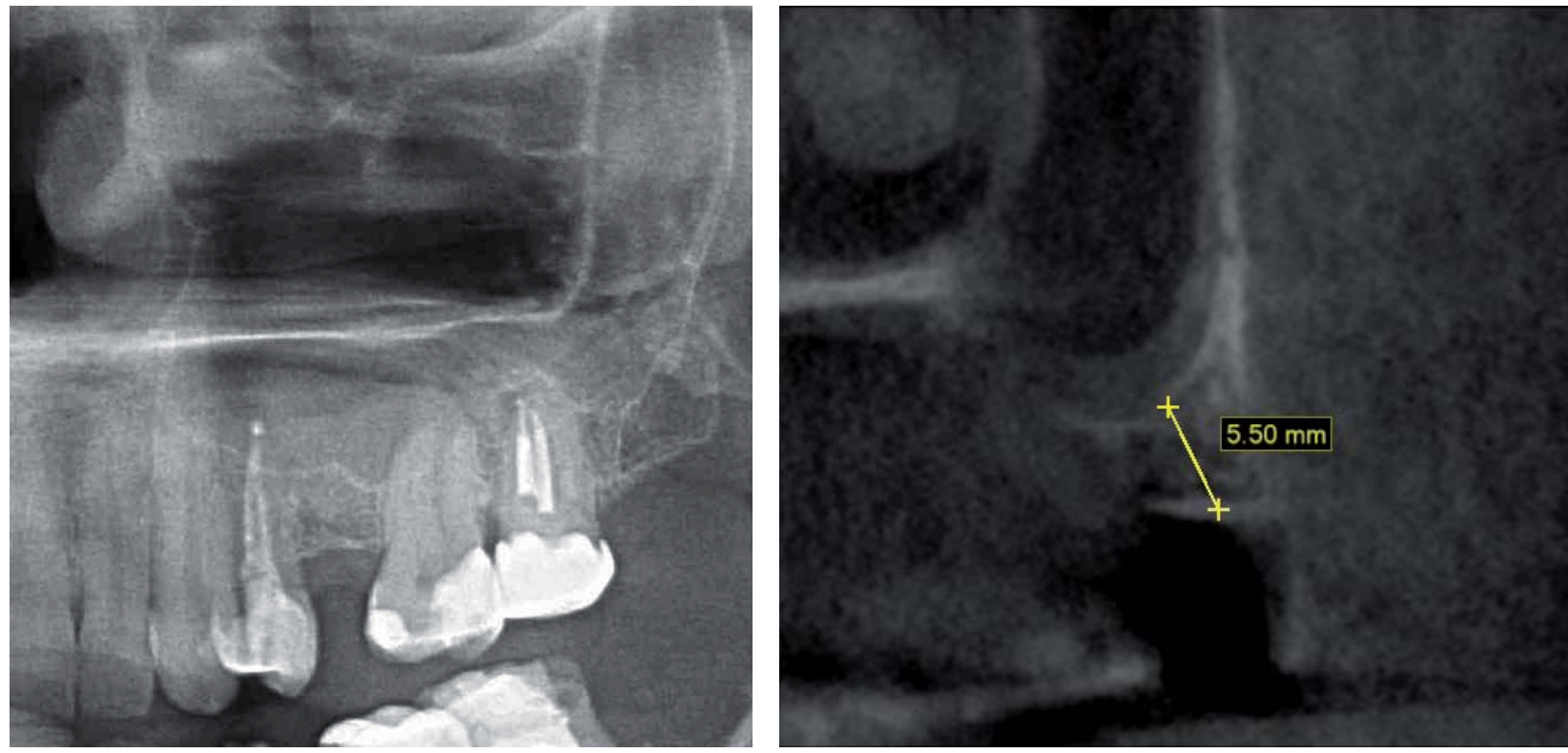

Rycina 5. Część zdjęcia ortopantomograficznego oraz rzutu CBCT z określoną grubością kości - przed zabiegiem Figure 5. Fragment of orthopantomographic image and CBCT cross-section with marked bone thickness - before surgery

Przy jej użyciu odpreparowana została też membrana Schneidera. Powstała przestrzeń została wypełniona nanocząsteczkowym hydroksyapatytem w roztworze wodnym (Nanogel firmy Teknimed). Kolejnym etapem zabiegu było wszczepienie implantu. Użyty został implant BEGO Semados RSX o średnicy $3,75 \mathrm{~mm}$ i długości $10 \mathrm{~mm}$ (Rycina 7). Uzyskana stabilizacja pierwotna wynosiła około $45 \mathrm{Ncm}$. Stan po wykonanym zabiegu widoczny jest na rycinie 8.

Po siedmiu dniach zostały usunięte szwy a po półrocznym okresie wgajania, który przebiegał bez powikłań, wykonano ostateczne uzupełnienie protetyczne w postaci korony ceramicznej cementowanej na łączniku tytanowym.

\section{Przypadek drugi}

Pacjentka została skierowana do leczenia implantologicznego po zakończonym leczeniu ortodontycznym. Powodem był przetrwały górny lewy mleczny kieł. Wcześniejsza diagnostyka RTG wykazała zatrzymanie stałego kła na wewnętrznej przyśrodkowej ścianie zatoki oraz zachyłek zatoki sięgający aż do zęba 21 (Rycina 9). Badanie CBCT wykazało, że wysokość wyrostka w lokalizacji zęba 23 wynosi 5,66 mm (Rycina 10).

Po konsultacji laryngologicznej zdecydowano o zachowaniu zatrzymanego zęba $23 \mathrm{w}$ jego pierwotnej lokalizacji, a w miejscu zęba mlecznego po wcześniejszym podniesieniu dna zatoki szczękowej wszczepiono implant (Ryciny 11 i 12).

Podniesienie dna zatoki szczękowej wykonałem metodą piezohydrodynamiczną, urządzeniem PIEZOMED firmy W\&H. Przez powsta-

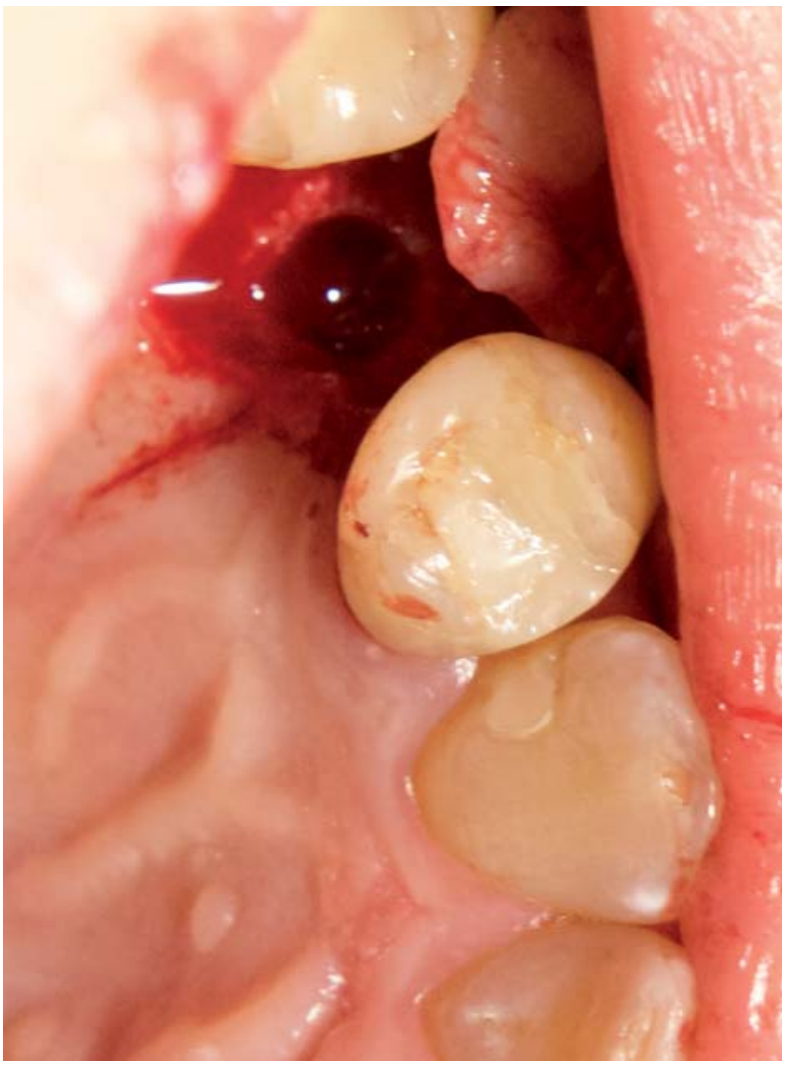

Rycina 6. Łoże implantu, przez które zostało podniesione dno zatoki szczękowej

Figure 6. Implant canal for maxillary sinus lift

ły otwór, który stanowi zarazem łoże implantu, wprowadziłem materiał augmentacyjny (Nanogel), a następnie wszczepiłem implant BEGO Semados RSX. 


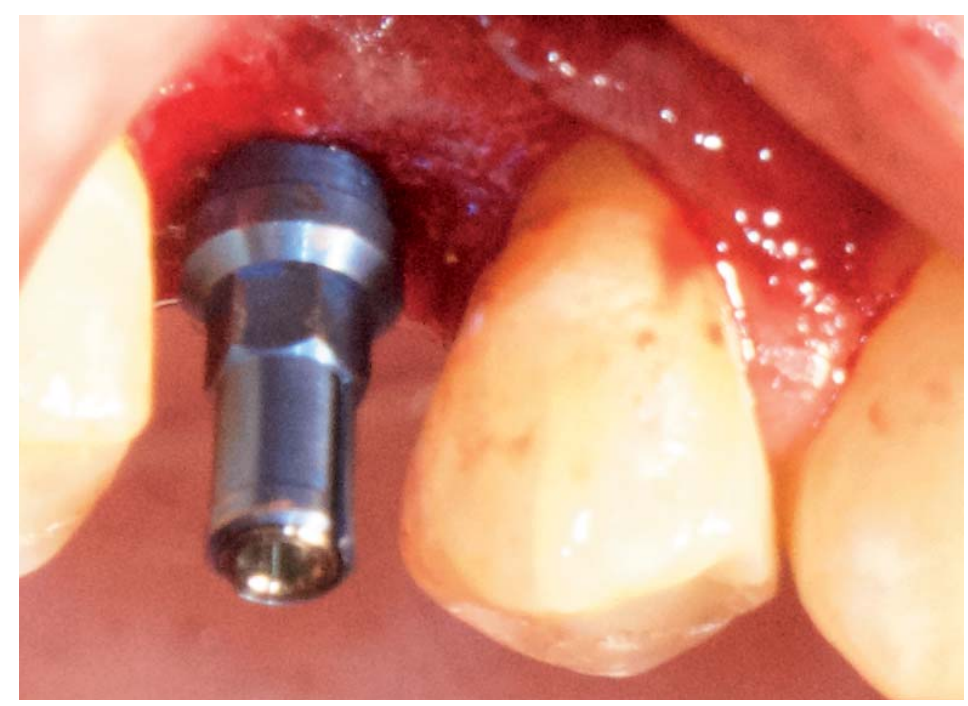

Rycina 7. Pozycja implantu śródkostnego w górnym łuku zębowym Figure 7. Intraosseous implant position in upper dental arch

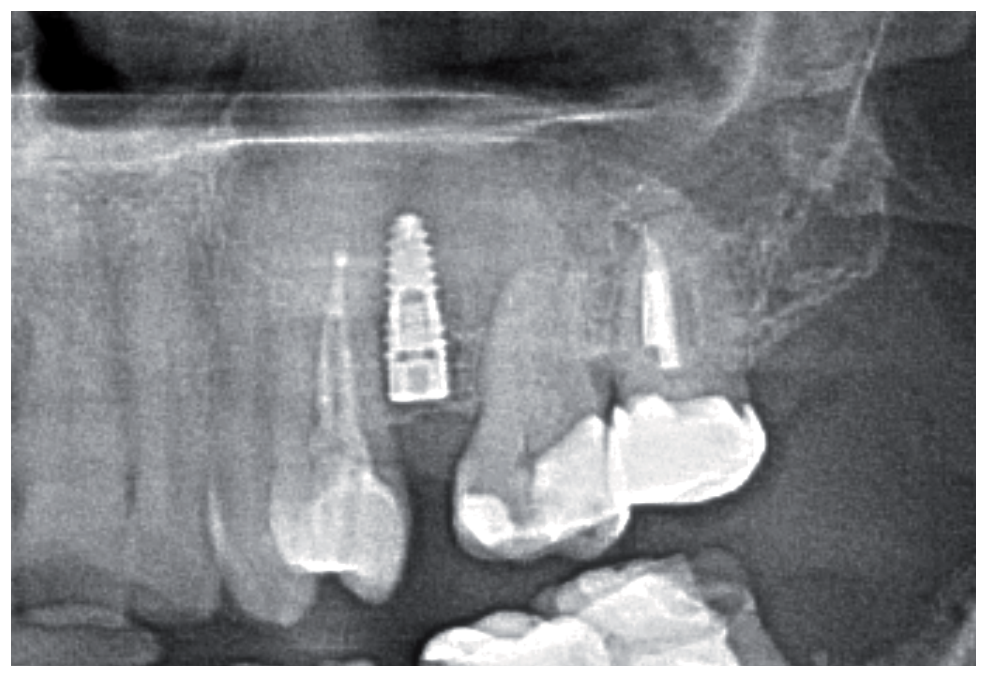

Rycina 8. Zdjęcie ortopantomograficzne po implantacji połączonej z podniesieniem dna zatoki szczękowej o kilka milimetrów Figure 8. Orthopantomographic image after implantation combined with maxillary sinus lift by several millimeters

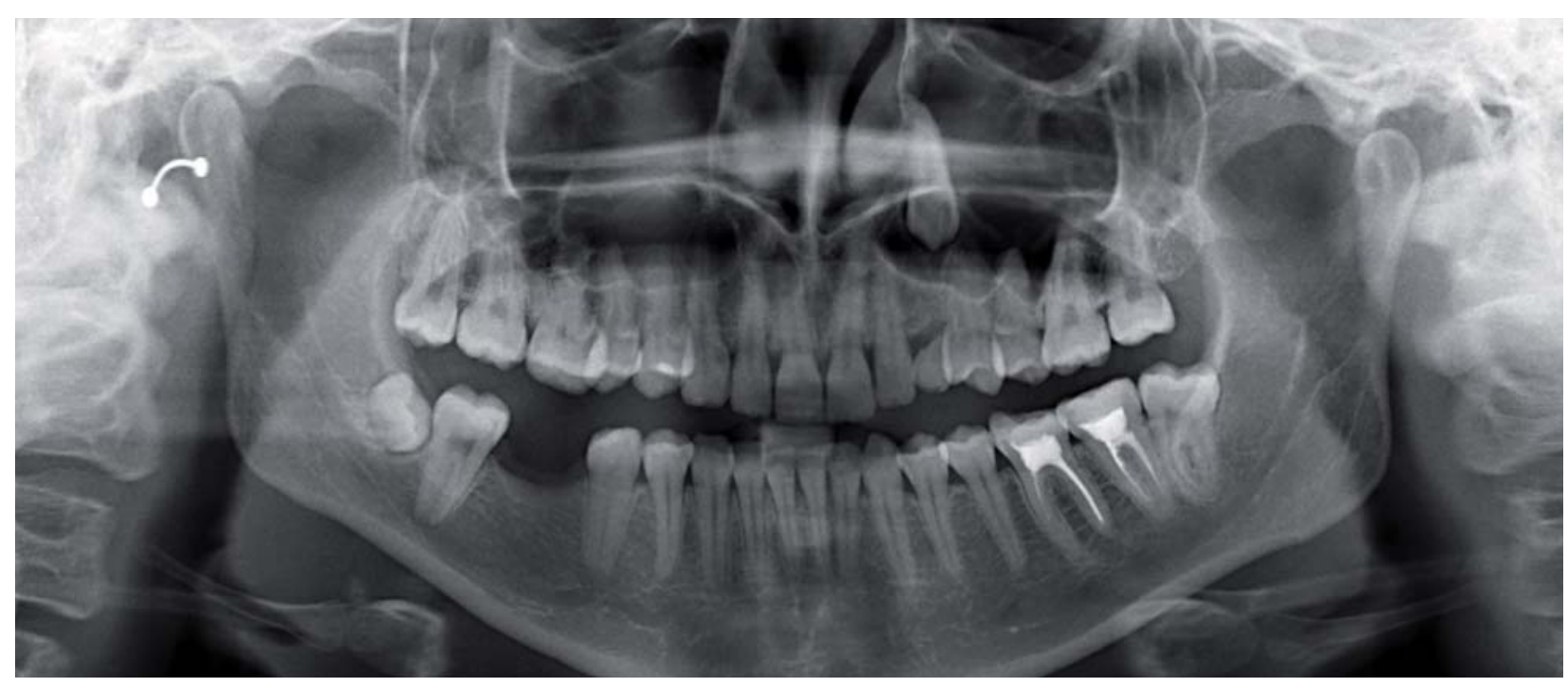

Rycina 9. Zdjęcie ortopantomograficzne przed zabiegiem

Figure 9. Orthopantomographic image before surgery 


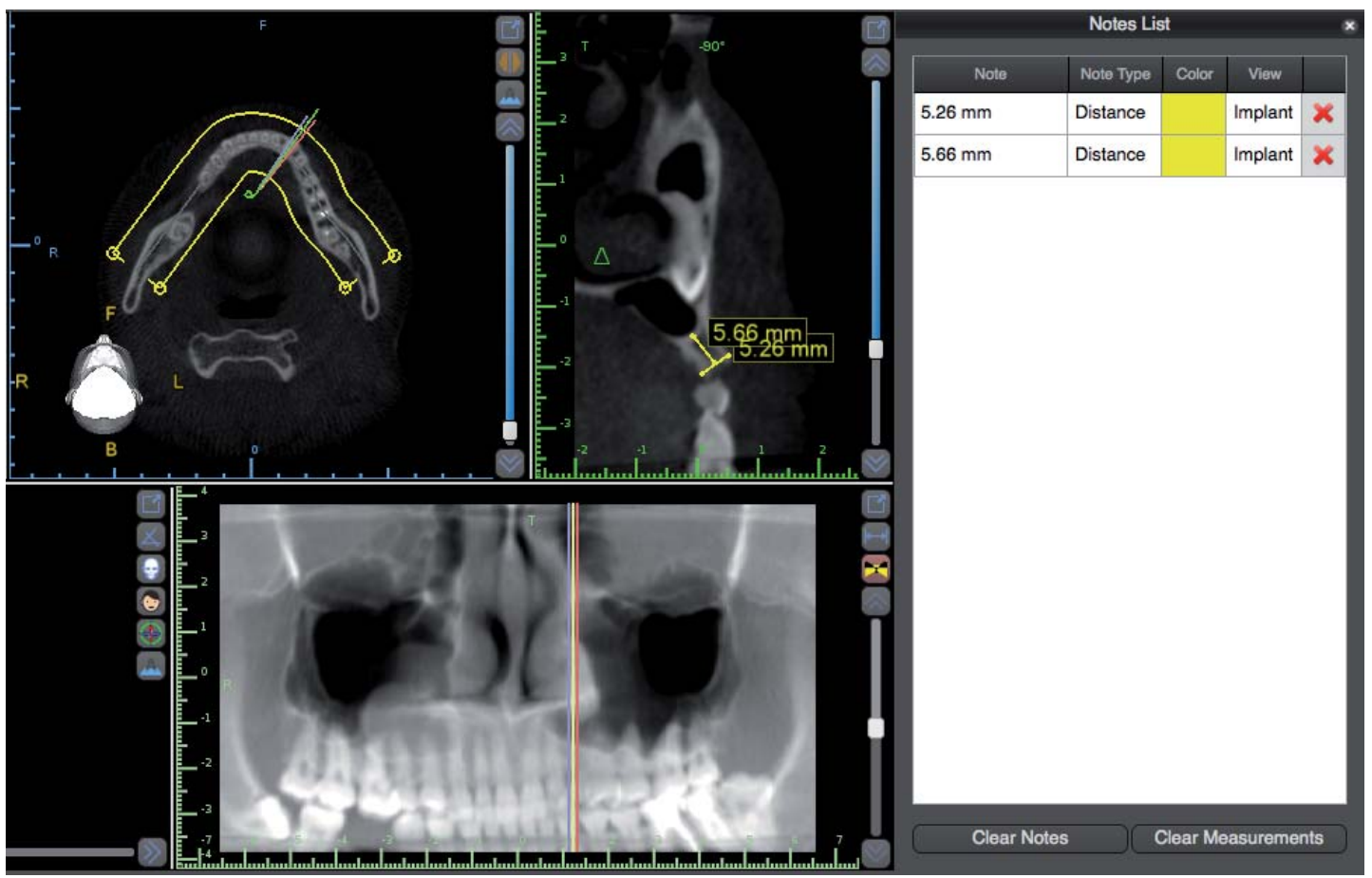

Rycina 10. Badanie CBCT przed zabiegiem chirurgicznym

Figure 10. CBCT examination before surgery

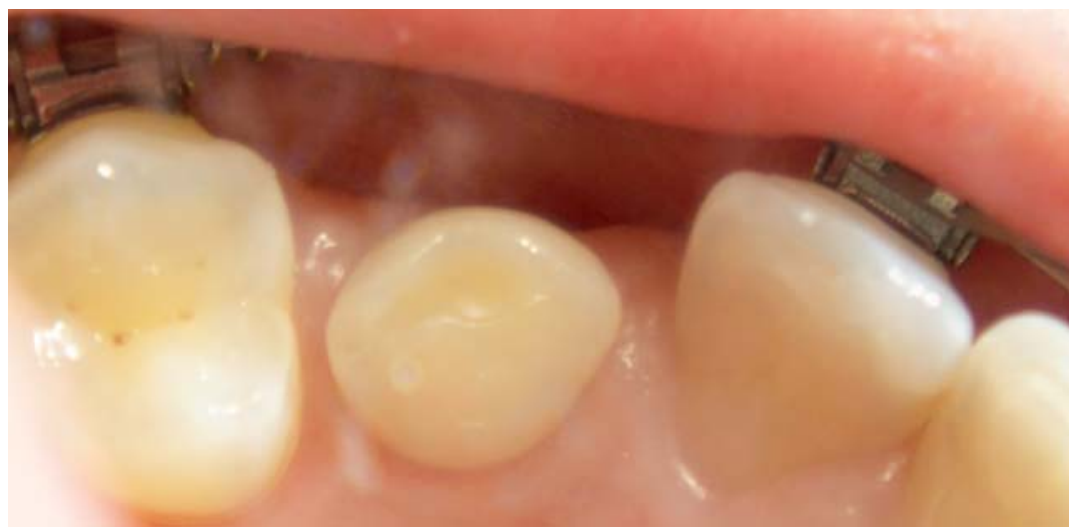

Rycina 11. Stan przed zabiegiem z przetrwałym mlecznym kłem

Figure 11. Existing deciduous canine before surgery

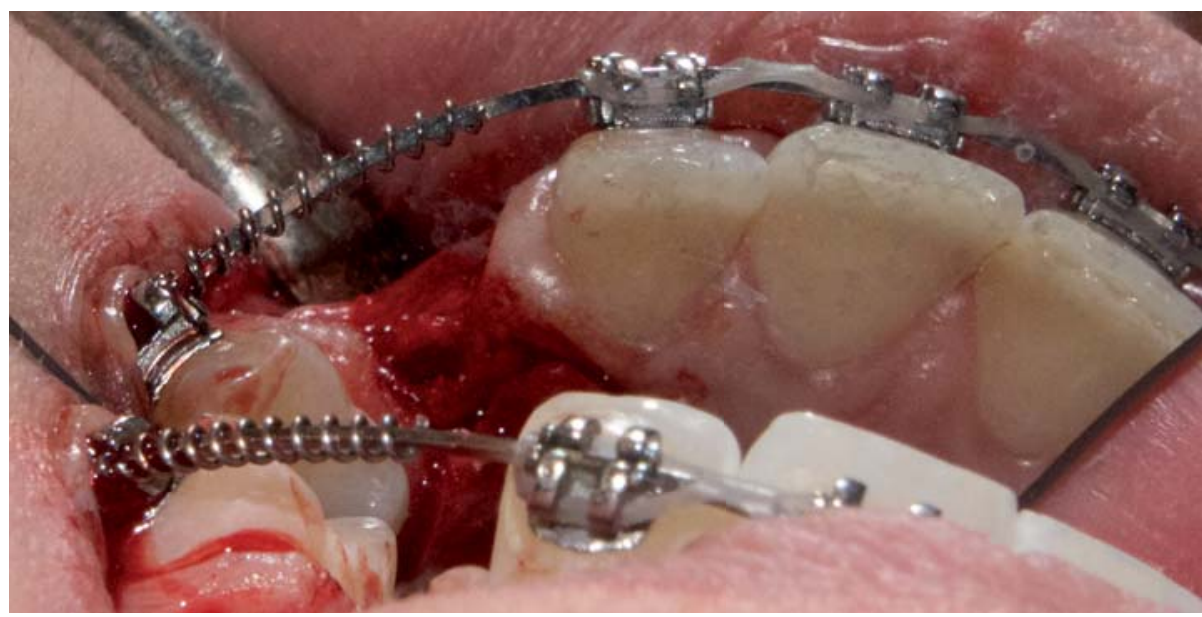

Rycina 12. Łoże implantu, przez które dokonano podniesienia dna zatoki szczękowej

Figure 12. Implant canal for maxillary sinus lift 
Pierwszym etapem zabiegu było usunięcie zęba mlecznego. Następnie za pomocą wiertła pilotującego wykonałem nawiert na głębokość około $4 \mathrm{~mm}$ (Rycina 12). Perforację ściany zatoki wykonałem końcówką urządzenia piezoelektrycznego i odpreparowałem nią membranę Schneidera. Łoże implantu zostało opracowane do średnicy $3,75 \mathrm{~mm}$ za pomocą wierteł $\mathrm{z}$ ka- sety systemu, a następnie do zatoki wprowadzono materiał kościozastępczy. Ostatnim etapem zabiegu było wszczepienie implantu BEGO Semados RSX o średnicy $3,75 \mathrm{~mm}$ i długości $11,5 \mathrm{~mm}$. Stabilizacja pierwotna implantu wyniosła $30 \mathrm{Ncm}$ (Rycina 13). Po zabiegu zostało wykonane kontrolne segmentowe zdjęcie RTG (Rycina 14).

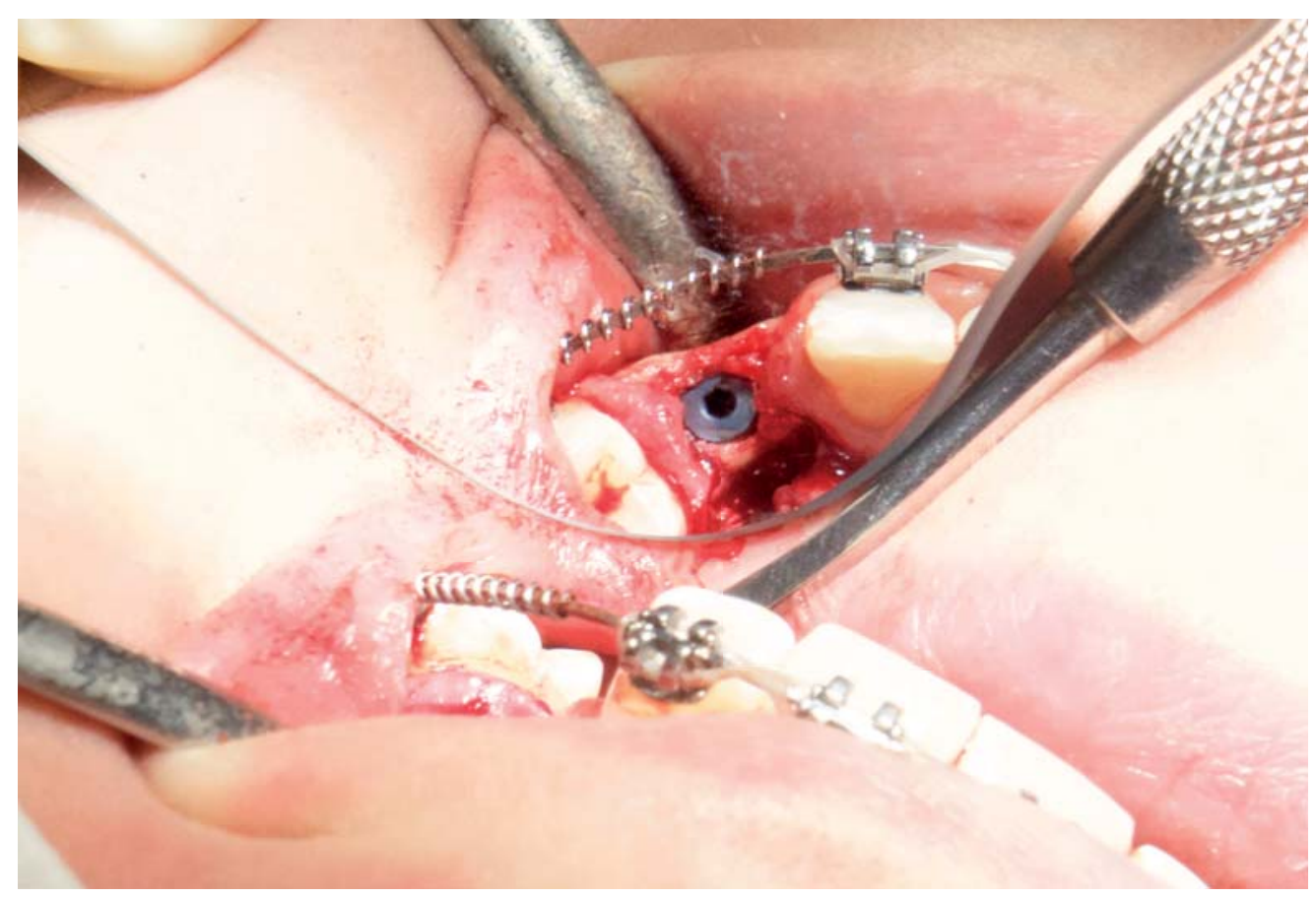

Rycina 13. Wszczepiony implant w strukturze kostnej po podniesieniu dna zatoki szczękowej Figure 13. Inserted implant in bone structure after maxillary sinus lift

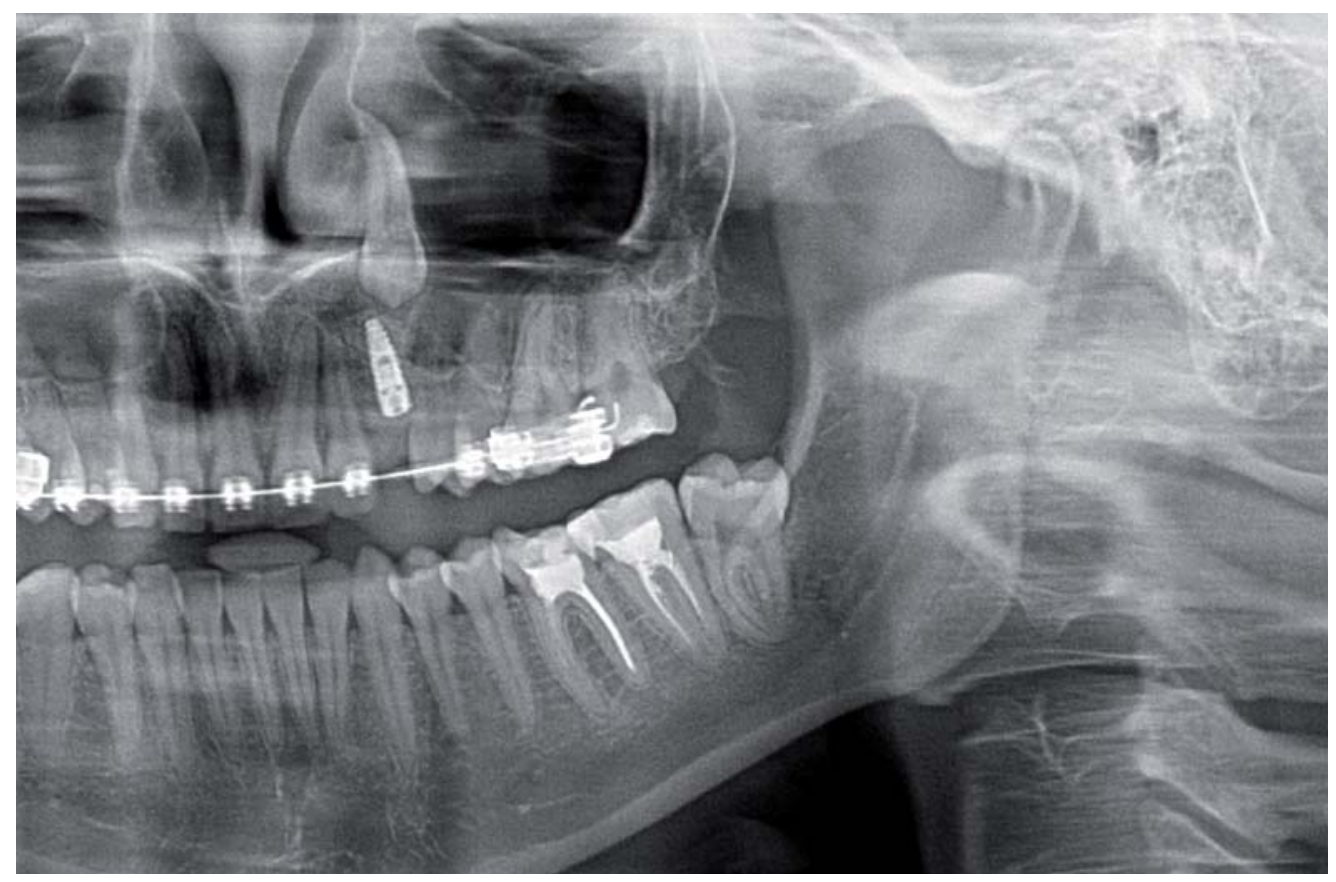

Rycina 14. Kontrolne zdjęcie ortopantomograficzne pozabiegowe

Figure 14. Control orthopantomographic image after surgery 


\section{Podsumowanie}

Zabieg podniesienia dna zatoki szczękowej w przeciągu kilku ostatnich lat stał się jedną z najczęściej wykonywanych procedur augmentacyjnych. Najczęściej wykonuje się go z dojścia bocznego, niemniej jednak w obecnym czasie dążenie do zmniejszenia traumatyczności i inwazyjności zabiegu powoduje, że piezohydrodynamiczne metoda podniesienia dna zatoki szczękowej przy użyciu urządzeń piezoelektrycznych staje się metodą z wyboru. Dzięki znacznemu ograniczeniu traumatyzacji tkanek dyskomfort pozabiegowy pacjenta jest mniejszy, a ryzyko powikłań ograniczone.

\section{Oświadczenia}

Oświadczenie dotyczące konfliktu interesów

Autorzy deklarują brak konfliktu interesów w autorstwie oraz publikacji pracy.

\section{Źródła finansowania}

Autorzy deklarują brak źródeł finansowania.

\section{References}

[1] Tatum H Jr. Maxillary and sinus implant reconstructions. Dent Clin North Am. 1986;30:207-29

[2] Summers RB. Sinus floor elevation with osteotomes. J Esthet Dent. 1998;10:164-71.

[3] Summers RB. A new concept in maxillary implant surgery: the osteotome technique. Compendium. 1994;15:152-62.

[4] Soltan M, Smiler DG. Antral membrane balloon elevation. J Oral Implantol. 2005;31:85-90.
[5] Torrella F, Pitarch J, Cabanes G, Anitua E. Ultrasonic ostectomy for the surgical approach of the maxillary sinus: a technical note. Int $\mathrm{J}$ Oral Maxillofac Implants. 1998;13:697-700.

[6] Troedhan AC, Kurrek A, Wainwright M, Jank S. Hydrodynamic ultrasonic sinus oor elevation--an experimental study in sheep. J Oral Maxillofac Surg. 2010;68:1125-30.

[7] Rocío Velázquez-Cayón, Manuel-María Romero-Ruiz, Daniel Torres-Lagares, Beatriz Pérez-Dorao, Marcel Wainwright, Camilo Abalos-Labruzzi, José-Luis Gutiérrez-Pérez. Hydrodynamic ultrasonic maxillary sinus lift: Review of a new technique and presentation of a clinical case. Med Oral Patol Oral Cir Bucal. 2012 Mar 1;17 (2):e271-5.

[8] Kfir E, Kfir V, Mijiritsky E, Rafaeloff R, Kaluski E. Minimally invasive antral membrane balloon elevation followed by maxillary bone augmentation and implant xation. $\mathrm{J}$ Oral Implantol. 2006;32:26-33.

[9] Tilotta F, Lazaroo B, Gaudy JF. Gradual and safe technique for sinus oor elevation using trephines and osteotomes with stops: a cadaveric anatomic study. Oral Surg Oral Med Oral Pathol Oral Radiol Endod. 2008;106:210-6.

Zaakceptowano do edycji: 2016-09-12 Zaakceptowano do publikacji: 2016-11-22

\author{
Adres do korespondencji: \\ ZIĘTEK Clinic \\ ul. Radzikowskiego 59/LU3, 31-315 Kraków \\ tel.: +48 601950616
}

e-mail: grzegorz.zietek@zietekclinic.com 